\title{
Effectiveness of Blockchain in overcoming barriers in Humanitarian Supply
}

\section{Chain}

\author{
Hrishikesh Palande ${ }^{1}$, Dr. Shilpa Parkhi ${ }^{2}$ \\ ${ }^{1}$ Symbiosis Institute of Operations Management, Plot No.A-23, Shravan Sector, New Cidco, Nashik, Maharashtra \\ ${ }^{2}$ Faculty, Symbiosis Institute of Operations Management, Plot No.A-23, Shravan Sector, New Cidco, Nashik, Maharashtra
}

\begin{abstract}
In the era of Industry 4.0 many new technologies are emerging and changing the status quo in many industries and sectors. On the other hand, people around the world are grappling with serious humanitarian issues of hunger, poor infrastructure effecting housing, education, healthcare. These problems are a result of complex causes ranging from natural disasters, environmental causes and human enforced causes such as ill governance, terrorism and forceable displacement of population belonging to certain communities. To address the humanitarian crisis global institutions are tirelessly working to assuage the suffering of people in crisis. Back bone of such initiatives is the Humanitarian Supply Chains which are often a complex linkage of Global non-profit organizations, private players, independent contractors, and local volunteers This paper aims at identifying the areas in humanitarian supply chain which can be improved by implementation of Blockchain technology. Barriers to humanitarian supply chains are identified from the extensive literature review. Using the responses received from experts in Humanitarian Supply Chains and Blockchain, an exploratory factor analysis was conducted giving us 4 factors in the context of Blockchain Implementation.
\end{abstract}

Keywords:

Blockchain, Humanitarian, Supply Chain, Barriers, Exploratory factor analysis

Article Received: 18 October 2020, Revised: 3 November 2020, Accepted: 24 December 2020

\section{Introduction}

The earliest mentions of the blockchain technology is in the whitepaper published in 2008 by Satoshi Nakamoto. The paper mentioned a tamper-proof, decentralized protocol. It was then, Bitcoin - a cryptocurrency was born as an alternative to the conventional banking system. Today a large number of Cryptocurrency networks are based on Blockchain. In 2013, Vitalik Buterin proposed Ethereum, a blockchain-based network on which Turing-complete scripts could be executed. Blockchain has found a wide range of applications in fintech, banking, logistics, international financial transaction, and data security. Over recent years blockchain has seen its application in Humanitarian Supply Chain(HSC),
Healthcare, Insurance, Asset management, and numerous other industries. Humanitarian crisis is on the rise as the world faces challenges in terms of environmental degradation, hatred against communities, terrorism and natural disasters. The world is experiencing a lot mankind displacement. A large sum of 70.8 million people around the world have been forced out of their home till 2018(UN, n.d.-a).International agencies like the UN are scrambling their specialized agencies to provide relief to refugees and people trapped in crisis within their own national boundaries. The World Food Programme (UNWFP) is actively seeking interest and has implemented pilot programs using Blockchain transactions. The UNWFP hasimplemented blockchain based cash benefit transfer system for 10,000 Syrian refugees 
in Jordan topurchase food using biometrics(UN, 2017).

UN and other global organizations have leveraged private players and Tech startups to assist them in implementation of blockchain enables aid. One such project is being run at Vanuatu, South pacific - one of the world's remote and hazard-prone locations. OXFAM Australia along with Sempo and Consensys - one of the world's largest blockchain firms have successfully implemented blockchain based direct cash transfer of Humanitarian aid to the community of people with limited access to internet, smartphones and electricity supply(Lin et al., 2019; Rust, 2019).Blockchain is stipulated to be an evolutionary and game changing technological which may change the status quo of the transactions worldwide. Humanitarian supply chain has a lot of barriers in effective implementation of resources as compared to commercial supply chains. Experts around the world are convinced that blockchain technology will help make humanitarian supply chain more effective. While it is widely agreed upon that blockchain technology will be helpful there is lack of well documented source addressing which barriers in particular could be overcome by application of blockchain based systems. This paper aims at conducting exploratory analysis to group these barriers in the context of blockchain implementation.

The remainder of the paper is organized as follows:Literature review, Methodology, Results,Future scope of research,Conclusion, Acknowledgement.

\section{Literature Review}

A lot on research has been done on use cases of blockchain in Supply chain, logistics and humanitarian aid. Researchers have also identified challenges and barriers in Humanitarian Supply Chains(B Balcik \& Beamon, 2008; Bremer, 2004; Kala, 2014; Raju \& Becker, 2013; Sandwell, 2011). Many of them are due to the inherent nature of operations in Humanitarian Supply Chains (Gustavsson, 2003).Many technological interventions have come up in Supply Chain and it has also got its application in Humanitarian Supply Chain. Blockchain as a technology can aid organizations in financial trust, integrity verification, data management, privacy, security, and governance(Casino et al., 2019; Drosatos \& Kaldoudi, 2019; Mackey \& Nayyar, 2017; Mettler \& Hsg, 2016; Modgil \& Sonwaney, 2019). As listed in table 2, researchers have studied barriers in Humanitarian Supply Chains. Technological barriers pose a great challenge to the supply and management of Humanitarian aid(Feng et al., 2012; Kabra \& Ramesh, 2015; Lee \& Zbinden, 2003; Maiers et al., 2005; Mbarika et al., 2005; Odedra-Straub, 1993). Political barriers such as regulations and mal practices are also a big hurdle(Kovacs \& Spens, 2009; Willner \& Zafeiridis, 2013). Organization barriers covers improper organizational structure and, insufficient resources, shortage of skilled workforce(Agostinho, 2013; Burcu Balcik et al., 2010; Fritz Institute, 2005; Gustavsson, 2003; Maiers et al., 2005; Natti \& Ojasalo, 2008). Inefficient management also causes lot of uncertainty and pressure on the HSCs (Kovacs \& Spens, 2009; Sahebi et al., 2017; Willner \& Zafeiridis, 2013). Humanitarian aid often goes beyond the regional and national boundaries, cultural differences among various stakeholders and interacting agencies is a hinderance to efficiently deliver the aid in cash or kind (Burcu Balcik et al., 2010; Fugate et al., 2006; Kovacs \& Spens, 2009; Schulz \& Alexander, 2010).Financial Barriershave been extensively covered by various UN Humanitarian reports and issues (B Balcik \& Beamon, 2008; UN, n.d.-b, 2017). But there was need forresearch which highlights specific barriers which can be removed by implementation of Blockchain. This research is an attempt to identify such barriers and classify then with context to Blockchain technology. 
Table 1: Barriers identified in Literature Review

\begin{tabular}{|c|c|c|}
\hline $\begin{array}{l}\text { Sr. } \\
\text { no. }\end{array}$ & Barrier & Category \\
\hline 1 & $\begin{array}{l}\text { Disparity in IT } \\
\text { infrastructure among actors }\end{array}$ & \multirow{7}{*}{$\begin{array}{l}\text { Technolog } \\
\text { ical } \\
\text { Barriers }\end{array}$} \\
\hline 2 & $\begin{array}{l}\text { Lack of time to share } \\
\text { knowledge }\end{array}$ & \\
\hline 3 & $\begin{array}{c}\text { Lack of accurate } \\
\text { information from affected } \\
\text { areas }\end{array}$ & \\
\hline 4 & Manual supply chain & \\
\hline 5 & Poor IT infrastructure & \\
\hline 6 & $\begin{array}{c}\text { Poor usage of technologies } \\
\text { such as Internet, Digital } \\
\text { wallets, GPS, robotics }\end{array}$ & \\
\hline 7 & $\begin{array}{l}\text { Weak warehousing and } \\
\text { logistics infrastructure }\end{array}$ & \\
\hline 8 & International regulations & \multirow{2}{*}{$\begin{array}{l}\text { Political } \\
\text { barriers }\end{array}$} \\
\hline 9 & $\begin{array}{l}\text { Unethical issues such as } \\
\text { theft, terrors, deception }\end{array}$ & \\
\hline 10 & $\begin{array}{c}\text { Fatigue amongst rescue and } \\
\text { humanitarian workers }\end{array}$ & \multirow{4}{*}{$\begin{array}{l}\text { Organizati } \\
\text { onal } \\
\text { barriers }\end{array}$} \\
\hline 11 & $\begin{array}{c}\text { Ineffective organizational } \\
\text { structure to share and } \\
\text { enhance knowledge }\end{array}$ & \\
\hline 12 & $\begin{array}{c}\text { Insufficient resources to } \\
\text { provide knowledge sharing } \\
\text { opportunities to workers }\end{array}$ & \\
\hline 13 & $\begin{array}{c}\text { Shortage of skilled } \\
\text { humanitarian workers }\end{array}$ & \\
\hline 14 & $\begin{array}{c}\text { Lack of proper training for } \\
\text { humanitarian workers }\end{array}$ & \multirow[t]{3}{*}{$\begin{array}{c}\text { Manageria } \\
1 \text { barriers }\end{array}$} \\
\hline 15 & $\begin{array}{l}\text { Lack of cooperation and } \\
\text { coordination amongst } \\
\text { interacting organizations }\end{array}$ & \\
\hline 16 & $\begin{array}{c}\text { Lack of real-time } \\
\text { monitoring of } \\
\text { reconstruction activities }\end{array}$ & \\
\hline
\end{tabular}

\begin{tabular}{|c|c|c|}
\hline 17 & $\begin{array}{l}\text { Lack of Integrated } \\
\text { management system }\end{array}$ & \\
\hline 18 & $\begin{array}{l}\text { Unstable managerial and } \\
\text { leadership positions in } \\
\text { humanitarian organizations }\end{array}$ & \\
\hline 19 & $\begin{array}{l}\text { Lack of financial trust in } \\
\text { Humanitarian organizations }\end{array}$ & \multirow[t]{2}{*}{$\begin{array}{c}\text { Financial } \\
\text { barriers }\end{array}$} \\
\hline 20 & $\begin{array}{c}\text { Traceability of funds and } \\
\text { expenditure tracking }\end{array}$ & \\
\hline 21 & $\begin{array}{c}\text { Cultural difference among } \\
\text { actors }\end{array}$ & \multirow[t]{4}{*}{$\begin{array}{l}\text { Cultural } \\
\text { Barriers }\end{array}$} \\
\hline 22 & $\begin{array}{l}\text { Inadequate information } \\
\text { sharing among actors }\end{array}$ & \\
\hline 23 & $\begin{array}{l}\text { Inefficient trust among } \\
\text { actors }\end{array}$ & \\
\hline 24 & $\begin{array}{c}\text { Insufficient knowledge } \\
\text { creation, enhancement and } \\
\text { sharing }\end{array}$ & \\
\hline
\end{tabular}

\section{Methodology}

\subsection{Rationale and purpose of the research}

Blockchain technology has being seem as a breakthrough when it comes to establishing amongst transacting organizations/parties, many pilot projects are being conducted by Humanitarian organizations at regional and global levels. As the technology is still in its earlier implementation, we tried to gather expert opinions regarding its effectiveness in overcoming barriers in Humanitarian Supply Chains (HSCs).

\subsection{Sampling}

As the population sample of experts working in implementation of Blockchain in Humanitarian Supply Chain is very limited. The sampling technique used was Judgmental/Expert sampling. The experts were chosen on the basis of literature review available, reports of blockchain based implementation in Humanitarian Supply Chain and experts from not for profit humanitarian 
organizations.

\subsection{Procedure}

We conducted interviews with these experts with experience in implementation of Blockchain in Humanitarian aid and relief. With the help of the discussion conducted we narrowed the list to 14 barriers as show in Table 2, the list was narrowed by eliminating common or highly correlated barriers as per the response we received from the experts. A questionnaire was prepared to capture expert views on the effectiveness of blockchain in overcoming these barriers. A conscious list of 74 experts was prepared and their responses to the question - Will blockchain be effective in overcoming these barriers? were captured on a Likert scale of 1 to 5 . 1 - Strongly Disagree, 2 Disagree, 3 - Not sure, 4 - Agree and 5 - Strongly Agree. The responses collected between July and September 2020 are used for analysis in this paper.

\section{Table 2: List of Barriers considered for further}

\section{analysis}

\begin{tabular}{|r|l|}
\hline Sr. no. & \multicolumn{1}{|c|}{ Barrier } \\
\hline 1 & Disparity in IT infrastructure among actors \\
\hline 2 & Lack of time to share knowledge \\
\hline 3 & Lack of accurate information from affected areas \\
\hline 4 & Poor usage of technologies such as Internet, Digital wallets, GPS, robotics \\
\hline 5 & Weak warehousing and logistics infrastructure \\
\hline 6 & International regulations \\
\hline 7 & Unethical issues such as theft, terrors, deception \\
\hline 8 & Lack of cooperation and coordination amongst interacting organizations \\
\hline 10 & Lack of real-time monitoring of reconstruction activities \\
\hline 11 & Lack of financial trust in Humanitarian organizations \\
\hline 12 & Traceability of funds and expenditure tracking \\
\hline 13 & Cultural difference among actors \\
\hline 14 & Insufficient knowledge creation, enhancement and sharing \\
\hline
\end{tabular}

\subsection{Statistical analysis}

In this paper Exploratory factor analysis (EFA) is used to identify if there is any factor structure in the barriers when it comes to Blockchain's effectiveness. For reliability of statistics we also calculated Cronbach's Alpha of 0.886 which gives We have used principal component factor extraction along with varimax rotation, as it gives clear interpretation of the factor structure by loading a variable highly on a factor there by minimizing loading on other factors(Thoma \& Gruber, 2020). The number of factors in this analysis was determined by the Kaiser rule, extracting factors with an eigenvalue larger than 1(Kaiser, 1960). KMO and Bartlett's test were performed, in this sample the result was 0.594 which is above the levels suggested by (Field, 2013) and the Bartlett test created produced a significant result of $(\mathrm{p}<0.001)$ which states significant correlations between items (Bartlett, 1954).

To get an unweighted factor score we calculated average of top barriers in each factor and then took average across all the responses.

\section{Results}

\subsection{Factor loading and unweighted factor scores}

The EFA using Principal Component Analysis and Varimax rotation with Kaiser normalization gave 4 factors with satisfactory KMO of 0.594which is above the limit suggested by (Field, 2013)and Bartlett result with $\mathrm{p}<0.001$ (Bartlett, 1954), thus validating the analysis.Factor 1 gave 8 barriers across infrastructure, Technological, cultural and organizational barriers, Factor 2 gave 2 barriers, Factor 3 yielded 2 barriers and Factor 4 yielded 2 barriers as well. Loading of items on factors is shown in Figure 1.

\begin{tabular}{|c|c|c|c|c|}
\hline \multicolumn{5}{|l|}{ Rotated Component Matrix ${ }^{\mathrm{a}}$} \\
\hline & \multicolumn{4}{|c|}{ Component } \\
\hline & Factor 1 & Factor 2 & Factor 3 & Factor 4 \\
\hline Unstable managerial and leadership positions in humanitarian organizations & 0.842 & & & \\
\hline Unethical issues such as theft, terrors, deception & 0.840 & & & \\
\hline Disparity in IT infrastructure among actors & 0.804 & & 0.327 & 0.303 \\
\hline Insufficient knowledge creation, enhancement and sharing & 0.803 & & & \\
\hline Cultural difference among actors & 0.775 & & & \\
\hline International regulations & 0.761 & 0.387 & & \\
\hline Weak warehousing and logistics infrastructure & 0.636 & 0.627 & & \\
\hline Poor usage of technologies such as Internet, Digital wallets, GPS, robotics & 0.612 & & & 0.477 \\
\hline Lack of real-time monitoring of reconstruction activities & & 0.920 & & \\
\hline Lack of cooperation and coordination amongst interacting organizations & & 0.865 & & \\
\hline Lack of time to share knowledge & & & 0.897 & \\
\hline Lack of accurate information from affected areas & 0.353 & & 0.819 & \\
\hline Traceability of funds and expenditure tracking & & & & 0.875 \\
\hline Lack of financial trust in Humanitarian organizations & & 0.493 & & 0.727 \\
\hline
\end{tabular}

Fig.1: Results from the exploratory factor analysis as obtained in the rotated component matrix.

\subsection{Factor scores}

The unweighted factor scores obtained by calculating average of top barriers(components) in 
each factor and then averaging across all the responses are shown in Figure 2.

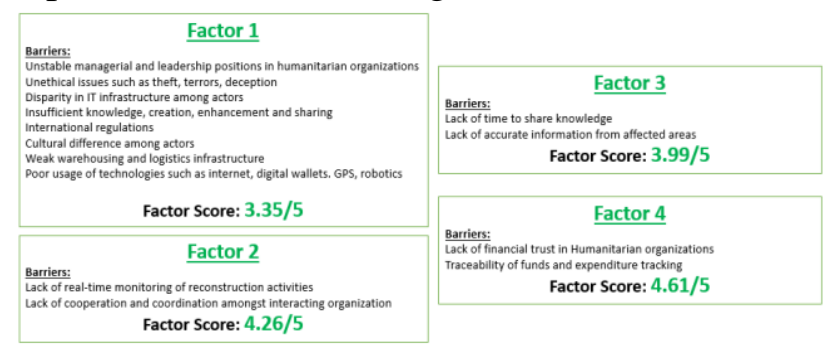

Fig. 2. Unweighted factor scores across all the response collected

\subsection{Interpretation of factors and these scores}

Factor 1 covers barriers belonging to infrastructure challenges, technological barriers and cultural \& organizational issues. As shown in Figure 1, it has got factor score of 3.35 out of 5 (lowest among all the factors). The scores can be interpreted as, blockchain will have the lowest chances of overcoming barriers loaded in this factor.

Factor 2 covers coordination and monitoring barriers in Humanitarian Supply Chain. As shown in Figure 1, it has got factor score of 4.26 out of 5 . This means Blockchain will be effective in overcoming barriers identified in this factor.

Factor 3 covers information and knowledge sharing barriers in Humanitarian Supply Chain. It has a factor score of 3.99 out of 5 , which is decent meaning blockchain will be fairly effective in overcoming these barriers.

Factor 4 covers financial and traceability barriers in Humanitarian Supply Chain. It has a factor score of 4.61 out of 5, which is the highest meaning blockchain will be most effective in overcoming these barriers.

Some important comments received during the course of interview and data collection are Current blockchain implementations are mainly in the areas where accountability and financial obligations are involved and without multi-party involvement blockchain will not offer value compared to other solutions, Blockchain's effectiveness can be further studies using cost benefit analysis, Automating complex processes through appropriate use of blockchain applications such as automating manual tracking and logging of supply chain data.

\section{Future Scope}

This paper aimed to identify barriers which can be removed or mitigated by deploying blockchain based systems. As part of the future scope we encourage to conduct cost benefit analysis or any other financial study for each barrier and factor. The research was done on the basis of responses and feedback received from the blockchain implementers and Humanitarian Supply Chain operators, a research done by collecting responses from beneficiaries of the blockchain based humanitarian aid program will give new perspective and validate this research.

\section{Conclusion}

A lot of research is being conducted in identifying the merits of blockchain as a technology, meanwhile Humanitarian Aid and relief organizations are facing with numerous challenges in the effective delivery of the aid - in cash or kind. With global issues such as refugee crisis, natural disasters and political instability on the rise; it is inevitable that the problems and their scale will also rise. This paper identifies the barriers in the context of Blockchain implementation. This research aims at helping Humanitarian supply chain players to recognize barriers that can be solved by deploying Blockchain and also barriers for which they will have to look beyond blockchain.

\section{Acknowledgement}

We thank experts from OXFAM - Australia, IBM, India Blockchain alliance, Cocreations, Consensys, Cognizant, InnovFin Consulting, Accenture, Mahindra Rise, TCS, Tata steel, International Management Institute, India and University of Northern Iowa for their prompt 
responses.

\section{References}

[1] Agostinho, C. F. (2013). Humanitarian Logistics: How to help even more? IFAC Conference on Management and Control of Production and Logistics, 46(24), 206-210. https://doi.org/10.3182/20130911-3-BR-3021. 00075

[2] Balcik, B, \& Beamon, B. M. (2008). Facility location in humanitarian relief. International Journal of Logistics, 11(2), 101-121. https://doi.org/10.1080/13675560701561789

[3] Balcik, Burcu, Beamon, B. M., Krejci, C. C., Muramatsu, K. M., \& Ramirez, M. (2010). Coordination in humanitarian relief chains : Practices, challenges and opportunities. Internal Journal of Production Economics, 126(1), 22-34. https://doi.org/10.1016/j.ijpe.2009.09.008

[4] Bartlett, M. S. (1954). A Note on the Multiplying Factors for Various $\chi 2$ Approximations. Journal of the Royal Statistical Society: Series B (Methodological), 16(2), 296-298. https://doi.org/10.1111/j.2517-6161.1954.tb0 0174.x

[5] BEG, SANA. "ISLAMIC ECONOMICS: AN ALTERNATE ECONOMIC SYSTEM FOR THE THIRD MILLENNIUM." International Journal of Business and General Management (IJBGM) 5. 5, Aug - Sep 2016; 1-12

[6] Bremer, R. (2004). Policy Development in Disaster Preparedness and Management: Lessons Learned from the January 2001 Earthquake in Gujarat , India. Prehosp Disaster Med, 18(4), 372-384. https://doi.org/10.1017/s1049023x00001345

[7] Casino, F., Dasaklis, T. K., \& Patsakis, C. (2019). A systematic literature review of blockchain-based applications : Current status, classification and open issues. Telematics and Informatics, 36(November 2018), 55-81. https://doi.org/10.1016/j.tele.2018.11.006

[8] Drosatos, G., \& Kaldoudi, E. (2019). Blockchain Applications in the Biomedical Domain: A Scoping Review. Computational and Structural Biotechnology Journal, 17, 229-240.

https://doi.org/10.1016/j.csbj.2019.01.010

[9] Elangovan, K., CB SENTHIL KUMAR, and S. Nallusamy. "Study on effect of Chennai metro rail limited routing system and its future growth." International Journal of Mechanical and Production Engineering Research and Development, 8 (1), 10791086 (2018).

[10]Feng, C., Yang, T., Li, X., Xiong, J., \& Xie, Q. (2012). Identifying Challenges of Humanitarian Logistics in China based on Stakeholder Theory. International Conference of Logistics Engineering and Management 2012 , $762-769$. https://doi.org/10.1061/9780784412602.0118

[11]Field, A. (2013). Discovering Statistics Using IBM SPSS Statistics. Sage edge.

[12]Fritz Institute. (2005). Logistics and the effective delivery of Humanitarian relief.

[13]Fugate, B., Sahin, F., \& Mentzer, J. T. (2006). Supply Chain Management Coordination Mechanisms. Journal of Business Logistics, 27(2), 129-161. https://doi.org/10.1002/j.2158-1592.2006.tb0 0220.x

[14] Gustavsson, L. (2003). Humanitarian logistics : context and challenges. Forced Migration Review, 6-8.

[15]Kabra, G., \& Ramesh, A. (2015). Analyzing ICT Issues in Humanitarian Supply Chain Management: A SAP-LAP Linkages Framework. Global Journal of Flexible 
Systems Management, 16, 157-171. https://doi.org/10.1007/s40171-014-0088-3

[16]Kaiser, H. F. (1960). The Application of Electronic Computers to Factor Analysis. Measurement, $\quad \mathrm{XX}(1), \quad 141-151$. https://doi.org/doi.org/10.1177/00131644600 2000116

[17]Kala, C. P. (2014). Deluge , disaster and development in Uttarakhand Himalayan region of India: Challenges and lessons for disaster management. International Journal of Disaster Risk Reduction, 8, 143-152. https://doi.org/10.1016/j.ijdrr.2014.03.002

[18] Ketaren, S. Otniel, et al. "Environmental health aspect in health emergency management (a case study: Sinabung Vulcanous Eruption)." Int. J. Appl. Nat. Sci. 5 (2016): 47-56.

[19] Kovacs, G., \& Spens, K. (2009). Identifying challenges in humanitarian logistics. International Journal of Physical Distribution \& Logistics Management, 39(6), 506-528. https://doi.org/10.1108/09600030910985848

[20]Lee, H. W., \& Zbinden, M. (2003). Marrying logistics and technology for effective relief. Forced Migration Review, 34-35.

[21]Lin, X., Xu, R., Chen, Y., \& Lum, J. K. (2019). A Blockchain-enabled Decentralized Time Banking for a New Social Value System. 2019 IEEE Conference on Communications and Network Security (CNS), 1-5. https://doi.org/10.1109/CNS.2019.8802734

[22] Mackey, T. K., \& Nayyar, G. (2017). A review of existing and emerging digital technologies to combat the global trade in fake medicines. Expert Opinion on Drug Safety, 16(5), 587-602.

https://doi.org/10.1080/14740338.2017.13132 27

[23]Maiers, C., Reynolds, M., \& Haselkorn, M.
(2005). Challenges to Effective Information and Communication Systems in Humanitarian Relief Organizations. 2005 IEEE International Professional Communication Conference Proceedings, 82-91. https://doi.org/10.1109/IPCC.2005.1494163

[24]Mbarika, V. W. A., Okoli, C., Byrd, T., \& Datta, P. (2005). The Neglected Continent of IS Research: A Research Agenda for Sub-Saharan Africa *. Journal of the Association for Information Systems, 6(5), 130-170.

[25]Mettler, M., \& Hsg, M. A. (2016). Blockchain Technology in Healthcare The Revolution Starts Here. 2016 IEEE 18th International Conference on E-Health Networking, Applications and Services, 16-18. https://doi.org/10.1109/HealthCom.2016.774 9510

[26]Modgil, S., \& Sonwaney, V. (2019). Planning the application of blockchain technology in identification of counterfeit Planning of in Planning the of technology counterfeit products : sectorial prioritization Planning the the application application of blockchain blockchain technology Plann. IFAC PapersOnLine, 52(13), 1-5. https://doi.org/10.1016/j.ifacol.2019.11.080

[27]Natti, S., \& Ojasalo, J. (2008). Case study Loose coupling as an inhibitor of internal customer knowledge transfer: findings from an empirical study in B-to-B professional services. Journal of Business \& International Marketing, 3(December 2006), 213-223. https://doi.org/10.1108/08858620810858472

[28]Odedra-Straub, M. (1993). Critical Factors Affecting Success of CBIS: Cases from Africa. Journal of Global Information Management, $\quad 1(3), \quad 16-31$. https://doi.org/10.4018/jgim.1993070102

[29]Raju, E., \& Becker, P. (2013). 
Multi-organisational coordination for disaster recovery: The story of post-tsunami Tamil Nadu , India. International Journal of Disaster Risk Reduction, 4, 82-91. https://doi.org/10.1016/j.ijdrr.2013.02.004

[30]Rust, B. (2019). UnBlocked Cash : Piloting accelerated cash transfer delivery in Vanuatu research report - Australian Aid, OXFAM.

[31] Sahebi, I. G., Arab, A., Reza, M., \& Moghadam, S. (2017). Analyzing the barriers to humanitarian supply chain management: A case study of the Tehran Red Crescent Societies. International Journal of Disaster Risk Reduction, 24, 232-241. https://doi.org/10.1016/j.ijdrr.2017.05.017

[32] Sandwell, C. (2011). A qualitative study exploring the challenges of humanitarian organisations. Journal of Humanitarian Logistics and Supply Chain Management, 1(2), 132-150. https://doi.org/10.1108/20426741111158430

[33] Schulz, S. F., \& Alexander, B. (2010). Horizontal cooperation in disaster relief logistics: Benefits and impediments. International Journal of Physical Distribution \& Logistics Management, 40(8), 636-656. https://doi.org/10.1108/09600031011079300

[34] TEJPAL, GAURAV, RK GARG, and ANISH SACHDEVA. "FACTOR ANALYSIS OF INSTITUTIONAL TRUST AMONG SUPPLY CHAIN PARTNERS IN INDIAN INDUSTRIES." International Journal of Industrial Engineering \& Technology (IJIET) 3.2, Jun 2013, 73-86

[35] Thoma, L., \& Gruber, J. (2020). Drivers and barriers for the adoption of cargo cycles: An exploratory factor analysis. Transportation Research Procedia, 46(2019), 197-203. https://doi.org/10.1016/j.trpro.2020.03.181

[36]UN. (n.d.-a). Global Issues - Refugees. https://www.un.org/en/sections/issues-depth/r efugees/

[37]UN. (n.d.-b). WFP Building Blocks. https://innovation.wfp.org/project/building-bl ocks

[38]UN. (2017). Usage of blockchain in the UN System. In Office of Information and Communications Technology.

[39] Velastegui, Santiago, et al. "Management of Humanitarian Logistics in the Stages Prior to Natural Disasters in Canton Ambato, Ecuador." Conference on Information Technologies and Communication of Ecuador. Springer, Cham, 2019.

[40]Willner, D., \& Zafeiridis, S. (2013). Challenges and the use of performance measurements in humanitarian supply chains (Issue May). https://doi.org/10.1108/09600030910985848 